\title{
Anticonvulsant activity of extracts from six Cameroonian plants traditionally used to treat epilepsy
}

\author{
Mireille Sylviane DONGMO NGUEPI ${ }^{1,2,3^{*}}$, Charles FOKUNANG ${ }^{3}$, \\ Fabrice FEKAM BOYOM ${ }^{2}$ and Asonganyi TAZOACHA ${ }^{3}$ \\ ${ }^{I}$ Department of Biochemistry and Molecular Biology, Faculty of Science, \\ University of Buea, PO Box 63 Buea, Cameroon. \\ ${ }^{2}$ Department of Biochemistry, Faculty of Science, University of Yaoundé 1, PO Box 812 Yaoundé, Cameroon. \\ ${ }^{3}$ Department of Physiological Sciences and Biochemistry, Faculty of Medicine and Biomedical Sciences, \\ University of Yaoundé 1, PO Box 1364, Yaoundé, Cameroon. \\ *Corresponding author; E-mail: syldong@yahoo.fr; Tel: 696510217
}

\begin{abstract}
Epilepsy remains one of the leading public health problems that affects about 50 million people worldwide, thus stressing the need for new anticonvulsant drug. This study was designed to evaluate the anticonvulsant activity against Penty lenetetrazole induced-convulsion in mice. Plants were extracted by maceration with water or organic solvents. The extracts were tested against PTZ-induced convulsion by measuring onset seizure, clonic seizure onset, convulsion duration, death time and percentage of protection. $A$. cordifolia leaf extract protected all animals from death at $1000 \mathrm{mg} / \mathrm{kg}$. A. muricata stem extract delayed seizures at 200 and $400 \mathrm{mg} / \mathrm{kg}$, while the onset of tonicoclonic (TC) seizures was significantly delayed at the highest doses tested for the seed extract $(800 \mathrm{mg} / \mathrm{kg}$ ). Stem and leaf extracts of A. senegalensis significantly delayed seizure onset at all doses. $D$. adescendes extract significantly protected mice from death. $F$. thonningii leaf extract at the smallest dose tested $(200 \mathrm{mg} / \mathrm{kg})$, significantly delayed the seizure onset and the occurrence of TC convulsions. Bark extract of $V$. doniana significantly delayed the seizure onset at all doses tested. The results obtained corroborate with the traditional claims that these plants can be a valuable source of new anticonvulsant compounds.
\end{abstract}

(C) 2014 International Formulae Group. All rights reserved.

Keywords: Plant extracts, PTZ-induced seizures, anticonvulsant effect, mice.

\section{INTRODUCTION}

Epilepsy is one of the most common neurological disorders with no age, social, sexual or geographical boundaries (WHO, 2001). It affects about 50 million people worldwide (Moshi et al., 2005). This epilepsy prevalence far exceeds those in developing countries (Baskind and Birbeck, 2005). In Cameroon, epilepsy prevalence reaches $6 \%$ in some endemic areas (Njamnshi et al., 2009a) such as Badissa in the Center region (Njamnshi et al., 2009b). In most societies, epilepsy is regarded as possession by evil spirits, and is seen as a highly contagious and shameful disease (Moshi et al., 2005). This stigma has long been recognized as a major burden to people with epilepsy and their families especially in sub-Saharan Africa 
where the combination of poverty, social role expectations, limited medical care, and traditional beliefs coalesce to severely limit their live span (Baskind and Birbeck, 2005).

In the developed countries, where drugs are easily available, epilepsy responds to treatment in up to $70 \%$ of the patients (Ilodigwe et al., 2010). However, in developing countries, $75 \%$ of people with epilepsy do not receive the appropriate treatment (WHO, 2001) and their epilepsy remains uncontrolled, rendering the patients unproductive in all spheres of life. In the scarcity of such drugs, they mainly rely on traditional medicines as the only mains of control in both rural and urban areas (Moshi et al., 2005) of these countries. In fact, $80 \%$ of the population relies on traditional medicines or folk remedies for their primary health care need (Hedge et al., 2009). In Cameroon, traditional indigenous medicine still plays an important role in epilepsy management with up to $25 \%$ of epileptic patients relying on traditional treatment (Njamnshi et al., 2009c). Medicinal plants are believed to be an important source of new drugs and lead compounds with potential therapeutic effects. The inclusion of those with proven safety and efficacy in the healthcare programs of developing countries is encouraged by the WHO because of the great potential they possess in combating various diseases (Chindo et al., 2009). Several plants used for the treatment of epilepsy in different systems of traditional medicine have shown activity when tested in modern bioassays for the detection of anticonvulsant activity (Hedge et al., 2009). In this line, the present work was designed to investigate the anticonvulsant activity of extracts from six medicinal plants traditionally used to treat epilepsy in Cameroon.

\section{MATERIALS AND METHODS}

Plant collection

The plant samples were collected in Yaoundé and its surroundings, Kon
Yambettain the center region and Bafou in the western region of Cameroon during the month of August 2010. The plant species were identified at the Cameroon National Herbarium in Yaoundé where voucher specimens were deposited under the following identification numbers:

Alchornea cordifolia (Euphorbiaceae): 4682/ SRFK

Annona muricata (Annonaceae): 3289/HNC

Annona senegalensis (Annonaceae): 40060/ HNC

Desmodium adescendes (Fabaceae): 10258/ $\mathrm{SRF} / \mathrm{CAM}$

Ficus thonningii (Moraceae): 44042/HCN

Vitexdoniana (Verbenaceae): 21147/SRF/ CAM

\section{Plants extraction and dosage preparation Plants extraction}

Leaves, seeds, stems, stem barks, twigs, or whole plants were harvested, shade dried and ground using a laboratory blender.100 g of powdered materials of $A$. cordifolia leaves, A. senegalensis twigs and leaves, $D$. adescendes (whole plant), and $V$. doniana stem barks were individually macerated in $1 \mathrm{~L}$ of $\mathrm{MeOH} / \mathrm{CH}_{2} \mathrm{Cl}_{2}$ (1:1) at room temperature for 72 hours. $100 \mathrm{~g}$ of $A$. muricata seed and stem and $F$. thoningii leaf and stem bark powders were similarly macerated in $1 \mathrm{~L}$ of EtOH and water respectively. Upon maceration, filtrates were prepared using Whatman paper $n^{\circ} 1$. The aqueous filtrate was dried in an oven (Memmert) at $45{ }^{\circ} \mathrm{C}$ for 48hours. The organic solvents were evaporated under reduced pressure using a rotary evaporator (BÜCHI) at $40{ }^{\circ} \mathrm{C}$ then 65 ${ }^{\circ} \mathrm{C}$ for the $\mathrm{MeOH} / \mathrm{CH} 2 \mathrm{Cl} 2$ (1:1) extract and at $80{ }^{\circ} \mathrm{C}$ for the ethanolic extract.

\section{Extracts dissolution and dosage preparation}

The extracts were diluted as needed for experiments each day. F. thonningii and $V$. doniana extracts were dissolved in water, while $A$. cordifolia and $D$. adescendes extracts were dissolved in DMSO/tween 20 and $A$. 
muricata and A. senegalensis were dissolved in olive oil. Extracts were tested at doses of 1000,700 and $500 \mathrm{mg} / \mathrm{kg}$ for $D$. adescendes and at 800,400 and $200 \mathrm{mg} / \mathrm{kg}$ for $A$. muricata, A, senegalensis, $F$. thonningii and $V$. doniana. The convulsion inducer, Pentylenetetrazole (PTZ) and the positive control, Phenobarbital (PHB) were purchased from Sigma Chemical. They were dissolved in normal saline. PTZ was prepared freshly for each experiment and administered intraperiton eally (ip) in a volume of $10 \mathrm{ml} / \mathrm{kg}$ body weight. Control animals received the same volume of vehicle.

\section{Animals}

Healthy male and female Balb/c mice (Mus musculus) of 6 to 8 weeks, weighing 20 to $24 \mathrm{~g}$ were used. They were housed at the animal house of the Faculty of Medicine and Biomedical Science of the University of Yaoundé 1 (Cameroon). Animals were separated into groups of 6 mice for experimentation and were maintained under standard conditions with free access to food and water ad libitum. All animals were fasted for $16 \mathrm{~h}$, but still allowed free access to water prior to experiments. Laboratory animal care and experimentation were performed under protocols approved by the animal care and use committee of the National Institute of Neurological Disorders and Stroke (NINDS) in strict compliance with the Guide for the care and use of laboratory animals of the National Research Council (National Research Council, 1996, National Academy Press, Washington, DC).

\section{Evaluation of the anticonvulsant activity}

A total of 31 experimental groups of 6 mice each were used for anticonvulsant evaluation using the method of Hosseinzadeh and Parvadeh (2004) with minor modifications.

\section{Statistical analysis}

All the results obtained were expressed as mean \pm standard deviation and were subjected to analysis of variance (ANOVA), and post hoc significance testing with Tukey's multiple comparison test using Graph pad 5.0 software. Significance was tested at 0.05 .

\section{RESULTS}

The results obtained from this study are presented and discussed below. The parameters recorded after administration of plant extracts and PTZ to mice at the dose of $90 \mathrm{mg} / \mathrm{kg}$ are summarized in Table 1 .

From Table 1, it appears that $A$. cordifolia leaf extract at up to $1000 \mathrm{mg} / \mathrm{kg}$ did not significantly modify $(\mathrm{P}>0.05)$ the time to seizure onset, nor the appearance of tonicoclonic (TC) convulsions; but the duration of convulsions was significantly reduced $(\mathrm{P}<0.05)$ at all doses compared to PTZ. All animals were protected from death at the dose of $1000 \mathrm{mg} / \mathrm{kg}, 50 \%$ of mice were protected from death at $700 \mathrm{mg} / \mathrm{kg}$.

A. muricata stem extract at 200 and 400 $\mathrm{mg} / \mathrm{kg}$ was able to delay seizures induced by PTZ in a significant manner $(\mathrm{P}<0.05)$, while the onset of TC seizures was significantly delayed $(\mathrm{P}<0.05)$ at the highest dose tested for seeds $(800 \mathrm{mg} / \mathrm{kg})$ and the smallest for stem $(200 \mathrm{mg} / \mathrm{kg})$. All doses of these extracts significantly reduced $(\mathrm{P}<0.05)$ seizure duration and an entire protection was observed for the stem and seed extracts at 200 $\mathrm{mg} / \mathrm{kg}$.

Twig and leaf extracts of $A$. senegalensis significantly delayed $(\mathrm{P}<0.05)$ seizure onset at $800 \mathrm{mg} / \mathrm{kg}$ while the seizure duration was significantly reduced $(\mathrm{P}<0.05)$ at all doses. None of these extracts significantly delayed $(\mathrm{P}>0.05)$ the time of onset of TC convulsions compared to the nontreated negative control, but they delayed the time of death. These extracts significantly delayed $(\mathrm{P}<0.05)$ the onset of seizure in a comparable manner to PHB at 10 and $20 \mathrm{mg} / \mathrm{kg}$. 
Table 1: Anticonvulsant activity of studied plants extracts.

\begin{tabular}{|c|c|c|c|c|c|c|}
\hline & $\begin{array}{c}\text { Dose } \\
\text { (mg/kg) }\end{array}$ & Seizure onset $(\mathrm{S})$ & $\begin{array}{c}\text { Clonic seizure } \\
\text { onset }(\mathbf{S})\end{array}$ & $\begin{array}{c}\text { Convulsion } \\
\text { duration }(\mathrm{S})\end{array}$ & Death time (S) & $\begin{array}{c}\% \\
\text { Protection }\end{array}$ \\
\hline \multicolumn{7}{|c|}{ Extracts } \\
\hline \multirow{3}{*}{$\mathrm{AlCl}$} & 500 & $59.67 \pm 7.84^{b}$ & $99.50 \pm 6.95^{b}$ & $50.83 \pm 7.65^{\mathrm{a}}$ & $261,50 \pm 44.49$ & 33.33 \\
\hline & 700 & $57.67 \pm 4.13^{b}$ & $143.20 \pm 59.05^{\mathrm{b}}$ & $98.00 \pm 8.78^{\mathrm{ab}}$ & $682.67 \pm 6.4^{\mathrm{a}}$ & 50 \\
\hline & 1000 & $67.17 \pm 11.83^{b}$ & $155.20 \pm 21.99^{\mathrm{b}}$ & $73.83 \pm 9.94^{\mathrm{ab}}$ & / & 100 \\
\hline \multirow{3}{*}{ AnMs } & 200 & $70.50 \pm 6.95^{b}$ & $124.00 \pm 11.46^{b}$ & $56.83 \pm 5.23^{\mathrm{a}}$ & I & 100 \\
\hline & 400 & $84.33 \pm 42.22^{b}$ & $94.00 \pm 1.41^{\mathrm{b}}$ & $93.00 \pm 20.73^{\mathrm{ab}}$ & $186.67 \pm 12.22 \mathrm{a}$ & 50 \\
\hline & 800 & $71.50 \pm 10.50^{\mathrm{b}}$ & $360.50 \pm 0.70^{\mathrm{ab}}$ & $72.00 \pm 10.13^{\mathrm{ab}}$ & $107.33 \pm 24.82^{\mathrm{a}}$ & 50 \\
\hline \multirow{3}{*}{ AnMst } & 200 & $132.67 \pm 10.05^{\mathrm{a}}$ & $280.00 \pm 14.14^{\mathrm{ab}}$ & $52.33 \pm 6.65^{\mathrm{a}}$ & I & 100 \\
\hline & 400 & $114.83 \pm 5.70^{\mathrm{a}}$ & $229.33 \pm 31.00^{\mathrm{b}}$ & $50.00 \pm 7.04^{\mathrm{a}}$ & l & 100 \\
\hline & 800 & $71.50 \pm 8.52^{\mathrm{b}}$ & $146.00 \pm 1.41^{\mathrm{b}}$ & $60.67 \pm 6.56^{\mathrm{a}}$ & $917 \pm 4.24^{\mathrm{a}}$ & 66.66 \\
\hline \multirow{3}{*}{ AnStw } & 200 & $69.83 \pm 10.06^{b}$ & $155.67 \pm 7.37^{b}$ & $46.00 \pm 7.7^{\mathrm{a}}$ & I & 100 \\
\hline & 400 & $69.17 \pm 9.49^{\mathrm{b}}$ & $111.00 \pm 11.40^{\mathrm{b}}$ & $49.50 \pm 9.64^{\mathrm{a}}$ & / & 100 \\
\hline & 800 & $89.00 \pm 19.75^{\mathrm{ab}}$ & $186 \pm 81.34^{\mathrm{b}}$ & $48.17 \pm 5.26^{\mathrm{a}}$ & 183 & 83.33 \\
\hline \multirow{3}{*}{ AnS1 } & 200 & $62.50 \pm 3.01^{\mathrm{b}}$ & $98.50 \pm 7.32^{\mathrm{b}}$ & $80.20 \pm 16.75^{\mathrm{ab}}$ & I & 100 \\
\hline & 400 & $61.50 \pm 3.01^{\mathrm{b}}$ & $126.00 \pm 1.82^{\mathrm{b}}$ & $55.00 \pm 8.57^{\mathrm{a}}$ & / & 100 \\
\hline & 800 & $102.50 \pm 12.19^{\mathrm{ab}}$ & $209.00 \pm 4.96^{\mathrm{b}}$ & $106.20 \pm 4.43^{\mathrm{ab}}$ & I & 100 \\
\hline \multirow{3}{*}{$\operatorname{DeA}$} & 500 & $63.33 \pm 3.67^{b}$ & $133.40 \pm 5.85^{\mathrm{b}}$ & $65.40 \pm 5.03^{\mathrm{a}}$ & I & 100 \\
\hline & 700 & $67.00 \pm 8.73^{\mathrm{b}}$ & $64.00 \pm 18.60^{\mathrm{ab}}$ & $59.40 \pm 26.86^{\mathrm{a}}$ & / & 100 \\
\hline & 1000 & $72.57 \pm 9.48^{\mathrm{b}}$ & $83.60 \pm 18.87^{\mathrm{ab}}$ & $72.60 \pm 9.15^{\mathrm{ab}}$ & 503 & 83.3 \\
\hline \multirow{3}{*}{ FiTsb } & 200 & $74.25 \pm 4.34^{\mathrm{b}}$ & $81.00 \pm 9.89^{b}$ & $146.00 \pm 13.92^{\mathrm{ab}}$ & l & 100 \\
\hline & 400 & $83.25 \pm 15.88^{b}$ & $132.25 \pm 63.20^{\mathrm{b}}$ & $48.75 \pm 8.53^{\mathrm{a}}$ & / & 100 \\
\hline & 800 & $64.29 \pm 20.62^{b}$ & $165.33 \pm 15.34^{\mathrm{b}}$ & $97.00 \pm 19.59^{\mathrm{ab}}$ & $207.50 \pm 57.27^{\mathrm{a}}$ & 66.66 \\
\hline \multirow{3}{*}{ FiTl } & 200 & $104.00 \pm 40.75^{\mathrm{ab}}$ & $257.00 \pm 74.57^{\mathrm{ab}}$ & $120.00 \pm 7.87^{\mathrm{ab}}$ & $302.50 \pm 57.27$ & 66.66 \\
\hline & 400 & $98.00 \pm 25.80^{\mathrm{ab}}$ & $286.00 \pm 8.18^{\mathrm{ab}}$ & $47.25 \pm 9.25^{\mathrm{a}}$ & / & 100 \\
\hline & 800 & $84.83 \pm 19.40^{\mathrm{b}}$ & $298.05 \pm 4.14^{\mathrm{ab}}$ & $84.75 \pm 18.99^{\mathrm{ab}}$ & I & 100 \\
\hline \multirow{3}{*}{ ViDsb } & 200 & $76.50 \pm 11.84^{b}$ & $121.75 \pm 39.30^{b}$ & $64.45 \pm 0.50^{\mathrm{a}}$ & $328.00 \pm 15.68$ & 33.33 \\
\hline & 400 & $92.17 \pm 33.30^{\mathrm{ab}}$ & $73.00 \pm 8.60^{\mathrm{ab}}$ & $96.20 \pm 20.31^{\mathrm{a}}$ & $343.25 \pm 56.64$ & 33.33 \\
\hline & 800 & $129.17 \pm 10.76^{\mathrm{ab}}$ & $77.50 \pm 10.40^{\mathrm{ab}}$ & $89.50 \pm 9.53^{\mathrm{a}}$ & $395.75 \pm 85.45$ & 33.33 \\
\hline \multicolumn{7}{|c|}{ Controls } \\
\hline PHB & 10 & $58.29 \pm 1.11^{\mathrm{b}}$ & $1468.0 \pm 10.08^{b}$ & $64.43 \pm 0.78^{\mathrm{a}}$ & $560.29 \pm 3.81^{\mathrm{a}}$ & 0 \\
\hline (ref & 20 & $67.00 \pm 3.57^{\mathrm{b}}$ & l & $57.83 \pm 0.753^{\mathrm{a}}$ & $1474.00 \pm 1.41^{\mathrm{a}}$ & 66.66 \\
\hline drug) & 40 & $194.86 \pm 2.67^{\mathrm{a}}$ & l & $43.00 \pm 2.16^{\mathrm{a}}$ & 1 & 100 \\
\hline PTZ & 90 & $46.13 \pm 6.19^{b}$ & $172.25 \pm 49.22^{\mathrm{b}}$ & $232.00 \pm 33.96$ & $374.63 \pm 39.46$ & 0 \\
\hline
\end{tabular}

D. adescendens, at doses of 500, 700 and $1000 \mathrm{mg} / \mathrm{kg}$, significantly protected $(\mathrm{P}<0.05)$ mice from death, but was ineffective in delaying either the seizure onset or that of the TC convulsions.
Leaf and stem bark extracts of $F$. thonningii significantly delayed $(\mathrm{P}<0.05)$ the seizure onset and the appearance of TC convulsions at $200 \mathrm{mg} / \mathrm{kg}$.

The bark extract of $V$. doniana significantly delayed $(\mathrm{P}<0.05)$ the seizure 
onset at all doses tested. Convulsion duration was significantly reduced compared to the nontreated negative control. Besides, the activity of this extract at $200 \mathrm{mg} / \mathrm{kg}$ was similar to that of PHB at $10 \mathrm{mg} / \mathrm{kg}$. All tested doses exhibited comparable levels of protection $(33.33 \%)$, but lower than that of the treated positive control; PHB with 66 and $100 \%$ at 20 and $40 \mathrm{mg} / \mathrm{kg}$ respectively.

All the tested extracts significantly reduced $(\mathrm{P}<0.05)$ the convulsion duration compared to negative control. $F$. thonningii leaves and stem bark $(800 \mathrm{mg} / \mathrm{kg}, 200 \mathrm{mg} / \mathrm{kg})$, D. adescendes at $1000 \mathrm{mg} / \mathrm{kg}$, A. senegalensis leaves $(800 \mathrm{mg} / \mathrm{kg}, 200 \mathrm{mg} / \mathrm{kg})$ and $A$. cordifolia $(700 \mathrm{mg} / \mathrm{kg}, 1000 \mathrm{mg} / \mathrm{kg})$ presented values far greater than that of the positive control group treated with the reference drug, phenobarbital (PHB).

\section{DISCUSSION}

Epilepsy is a common neurological condition associated with an alteration in psychological, emotional and educational parameters (Aldarmaa et al., 2010).

Prevention of PTZ induced seizures in laboratory animals is the most commonly used initial screening test for discovery of anticonvulsant drugs. It is mostly believed that inhibitors exert the iraction by acting as antagonists at the picrotoxinin-sensitive site at the $\gamma$-aminobutyric acid $\left(\mathrm{GABA}_{\mathrm{A}}\right)$ receptor complex (Hansen et al., 2004). Accordingly, Huang et al. (2001) indicated that PTZ interacts with overlapping but distinct domains of the $\mathrm{GABA}_{\mathrm{A}}$ receptor. Within 2-4 seconds of PTZ administration, there is an increase in blood oxygen levels. This increase was observed at the thalamus, especially the anterior thalamic nuclei. The peak of this activity which is twofold greater than in all other thalamic areas is reached few seconds before the first seizure (Brevard et al., 2006).

Extracts from $F$. thonningii, a plant of the Moraceae family presented a significant anticonvulsant effect against PTZ-induced convulsion. No previous scientific study had ever revealed its anticonvulsant activity but however, Noumi and Fozi (2003) reported the use of a related plant (Ficus sycomorus) in combination with other plants such as Asystasia gangetica, Ficus mucoso, and Aframamum melegueta in Fongo-Tongo community in Cameroon to cure epileptsy. Beside this report, Tanzanian healers have been reported to boil the bark of Ficus sycomorus in the treatment of epilepsy (Moshi et al., 2005). Another study conducted by Sandabe et al. (2003) revealed that aqueous extract of $F$. sycomorus stem bark at the doses of 200 and $400 \mathrm{mg} / \mathrm{kg}$ protected laboratory animals from death while Ibrahim et al., (2008), using the flavonoid fraction of F. sycomorus, obtained an anticonvulsant activity against the PTZ and maximal electroshock seizure (MES) models at 10 $\mathrm{mg} / \mathrm{kg}$. Singh and Goel (2009), working on another species of the same genus, Ficus religiosa, observed that the methanolic extract of figs at the maximum dose tested (100 $\mathrm{mg} / \mathrm{kg}$ ) was not effective against the PTZ model but was able to protect animal from MES seizure starting at $25 \mathrm{mg} / \mathrm{kg}$, the smallest dose tested. Similarly, the saponin fraction of the same plant at $1 \mathrm{mg} / \mathrm{kg}$ was able to decrease PTZ-induced seizures (Singh et al., 2013). Another species, Ficus platyphylla, studied by Chindo et al. (2009) revealed that saponins extracted from the stem bark, tested at the minimal dose $(25 \mathrm{mg} / \mathrm{kg})$ were effective against in vivo and in vitro models of epilepsy. In our study, leaves and stem bark of $F$. thonningii at $200 \mathrm{mg} / \mathrm{kg}$, the smallest dose tested, significantly delayed the onset of seizures in general and tonicoclonic seizures in particular. At this dose, the stem bark extract entirely protected the animals, while $66.66 \%$ of mice were protected by leaf extract.

An ethnobotanical survey of epilepsy treatment in Fongo-Tongo village, Western region of Cameroon by Noumi and Fozi (2003), revealed the use of $D$. adescendes leaves, $V$. doniana and $A$. senegalensis stem bark as drugs against epilepsy. They were effective when given to some epileptics who 
claimed to be cured after an average period of 18 months. The ethanolic extract of $D$. adescendes tested at $300 \mathrm{mg} / \mathrm{kg}$, was effective against clonic convulsions induced by PTZ as reported by N'gouemo et al. (1997). In our study, the ethanolic extract of $D$. adescendes was able to protect mice from death at all doses tested, but was neither effective against seizure onset nor tonicoclonic seizures. Concerning A. senegalensis, Konate et al. (2012) reported the anticonvulsant property of the methanolic extract and aqueous fraction of the stem bark of $A$. senegalensis at $400 \mathrm{mg} / \mathrm{kg}$. This result is different from what we obtained at the same dose and could be explained by the plant part used in our study or extraction solvent used. However, the activity observed at $800 \mathrm{mg} / \mathrm{kg}$, particularly the onset seizure in our study confirmed the anticonvulsant property of this plant which did reduce the convulsion duration at all doses tested.

A. muricata stem extract at 200 and 400 $\mathrm{mg} / \mathrm{kg}$ significantly delayed seizures, while the onset of TC seizures was significantly delayed at 200 and $800 \mathrm{mg} / \mathrm{kg}$ for the stem and seeds respectively. Our findings are similar to those obtained by N'gouemo et al. (1997) with the ethanolic extract of leaves of this plant at the dose of $300 \mathrm{mg} / \mathrm{kg}$. Twigs and seeds significantly reduced seizure duration and conveyed entire protection at $200 \mathrm{mg} / \mathrm{kg}$ body weight in mice.

A. cordifolia leaves did not significantly modify the time to seizure onset, nor the onset of tonicoclonic (TC) convulsions, but significantly reduced the duration of convulsions. In the contrary Pedersen et al. (2009) in a previuous study showed inhibition of spontaneous epileptic form discharges by the ethanolic extract of $A$. cordifolia leaves from Mali. This difference could be due to the difference in solvents used, or in the in vitro model compared to the in vivo approach used in our study. In fact, the in vitro active compounds could have been metabolized to non-active derivatives in the animal's organism or did not cross the blood brain barrier. Otherwise, the active compounds present in the extract do not show effect on the PTZ model (Pedersen et al., 2009).

A comparison between the different extracts, show that the extract A. Muricata stem bark at 200 and $400 \mathrm{mg} / \mathrm{kg}, A$. senegalensis stem bark and leaves at 800 $\mathrm{mg} / \mathrm{kg}$, F. thonningii leaves at 200 and 400 $\mathrm{mg} / \mathrm{kg}$ and $V$. doniana at 400 and $800 \mathrm{mg} / \mathrm{kg}$ were able to delay seizure onset with the best activity observed for the A. muricata stem bark extract.

The protection offered by plant extracts might be dependent upon synergistic effects of constituents. Indeed, phytochemical analysis of organs of these plants revealed the presence of alkaloids, saponins, tanins, anthraquinones, terpenoids, and flavonoids in the ethanolic and aqueous leaf extracts of $V$. doniana (Agbafor and Nwachukwu, 2011). Ayodele et al., (2007) working on the ethanolic extract of the leaves of A. cordifolia, found alkaloids, tannins, saponins, flavonoids and steroidal ring. The authors also stated a relationship between $A$. cordifolia intake and the prevention of neurodegenerative disease. A literature review, conducted by Rastogi et al. (2011), revealed that D. adscendens contains triterpenoids, saponins, tetrahydroisoquinolones, phenyle thylamines and indole-3-alkyl amines isolated from the leaves. Three active components were identified as the known triterpenoid glycosides dehydrosoya saponin I (DHS-I), soya saponin I and soya saponin III. Dehydrosoya saponin, the major saponin compound of the plant was the most potent potassium channel opener. As in the case with plants of the Annonaceae family, tannins, steroids and cardiac glycosides were the major compounds found in A. muricata (Gajalakshmi et al., 2012), while Arthur et al. (2011) working with the leaf aqueous extract of A. muricata found that saponins and flavonoids are also present in the plant. Another report by Boyom et al. (1996) revealed the presence of sesquiterpernes, particularly $\beta$ - caryophyllene. As concerns $A$. 
senegalensis, alkaloids, terpenoids, particularly monoterpenes were reported by Boyom et al. (1996). Saponins, another compound present in $A$. senegalensis was found in the aqueous extract of root bark (Konate et al., 2012). Added to this, resins, alkaloids, proteins, anthraquinones, sterols, glycosides and terpenes were also present in A. senegalensis (Adzu et al., 2005).

Some extracts showed no effects in our study despite traditional claims, particularly concerning the onset of seizures, but they were all able to reduce the convulsion duration. Differences in metabolism between rodents and humans might explain such differences and justify the use in traditional medicine despite the lack of effect in the animal model (Pedersen et al., 2009).

As far as the mechanism of action are concerned, the extract either increases the threshold of PTZ- induced convulsion or protects mice against convulsions induced by PTZ. Clonic seizures induced by PTZ are blocked by drugs that reduce T-type calcium currents and drugs that enhance inhibitory neuro-transmission by GABAA receptors (benzodiazepine, phenobarbital and valproate) (Chindo et al., 2009). The fact that the extracts protected animal against PTZ-induced seizures may suggest that they contain compounds that facilitate GABAergic transmission (Ayanniyi and Wannang, 2008).

Despite the diversity of models that could potentially be used to screen for anticonvulsant activity, PTZ-induced acute seizures remains 'Gold standard' in the early stages of testing. The PTZ model is assumed to identify anticonvulsant drugs effective against petit mal seizures. The effects of extracts against PTZ-induced seizures thus suggest anticonvulsant efficacy against petit mal epilepsy in man (Chindo et al., 2009).

\section{Conclusion}

The pharmacological screening of the extracts of Cameroonian plants traditionally used against epilepsy, led to the identification of several extracts with potential anticonvulsant properties. However further investigation using other models of epilepsy are required to characterize their anticonvulsant and antiepileptic effects.

\section{ACKNOWLEDGEMENTS}

The authors wish to show their sincere gratitude to Pr Tshala Desire of OHSU, USA for providing the reagents used for this study.

The authors declare that there is no conflict of interest regarding the publication of this manuscript.

\section{REFERENCES}

Adzu B, Abubakar MS, Izebe KS, Akumka DD, Gamaniel KS. 2005. Effect of Annona senegalensis root bark extracts on Najanigricotlisnigricotlis venom in rats. Journal of Ethnopharmacology, 96: 507-513.

Agbafor KN, Nwachukwu N. 2011. Phytochemical analysis and antioxidant property of leaf extracts of Vitexdoniana and Mucunapruriens. Biochemistry Research International, 2011: 459839.

Aldarmaa J, Liu Z, Long J, Mo X, Ma J, Liu J. 2010. Anticonvulsant effect and mechanism of Astragalusmongholicus extract in vitro and in vivo: protection against oxidative damage and mitochondrial dysfunction. Neurochemistry Research, 35: 33-41.

Arthur FKN, Woode E, Terlabi EO, Larbie C. 2011. Evaluation of acute and subchronic toxicity of Annona muricata (Linn.) aqueous extract in animals. European Journal of Experimental Biology, 1(4): 115-124.

Ayanniyi RO, Wannang NN. 2008. Anticonvulsant activity of the aqueous leaf extract of Croton zambesicus (Euphorbiaceae) in mice and rats. Iranian journal of pharmacology \& therapeutics, 7: 79-82.

Ayodele OK, Olaleye MT, Ajele JO. 2007. Antioxidant properties and glutathione Stransferases inhibitory activity of Alchornea cordifolia leaf extract in 
Acetaminophen-induced liver injury. Iranian Journal of Pharmacology \& Therapeutics, 6: 63-66.

Baskind R, Birbeck GL. 2005. Epilepsyassociated stigma in sub-Saharan Africa: The social landscape of a disease. Epilepsy \& Behavior, 7: 68-73.

Boyom FF, Amvam ZPH, Menut C, Lamaty G, Bessiere JM. 1996. Aromatic plants of Tropical Central Africa. Part XXVII. Comparative Study of the Volatile Constituents of Five Annonaceae Species Growing in Cameroon Flavour and Fragrance Journal, 11(6): 333-338.

Brevard ME, Kulkarni P, King JA, Ferris CF. 2006. Imaging the neuronal substrates involved in the genesis of the penty lenetetrazole-induced seizures. Epilepsia, 47(4): 745-754.

Chindo BA, Anuka JA, McNeil L, Yaro AH, Adamu SS, Amos S, Connelly WK, Lees G, Gamaniel KS. 2009. Anticonvulsant properties of saponins from Ficus platyphylla stem bark. Brain Research Bulletin., 78(6): 276-282.

Gajalakshmi S, Vijayalakshmi S, Devi RV. 2012. Phytochemical and pharmacological properties of Annona muricata: a review. International Journal of Pharmacy and Pharmaceutical Sciences, 4(2): 3-6.

Hansen SL, Bonnie BS, Sanchez C. 2004. Anticonvulsant and antiepileptogenic effects of GABA A receptor ligands in pentylenetetrazole-kindled mice. Progress in Neuro-Psypharmacology and Biological Psychiatry, 28: 105-113.

Hegde K, Thakker SP, Joshi AB, Shastry CS, Chandrashekhar 2009. Anticonvulsant activity of Carissa carandas Linn. root extract in experimental mice. Tropical Journal of Pharmaceutical Research, 8(2): 117-125.

Hosseinzadeh H, Parvardeh S. 2004. Anticonvulsant effects of thymoquinone, the major constituent of Nigella sativa seeds, in mice. Phytomedicine, 11(1): 5664.
Huang R, Bell-Horner CL, Dibas MI, Covey DF, Drewe JA, Dillon GH. 2001. Pentylenetetrazole-Induced Inhibition of Recombinant $\gamma$ Aminobutyric Acid Type A $\left(\mathrm{GABA}_{\mathrm{A}}\right)$ Receptors: Mechanism and Site of Action. The Journal of Pharmacology and Experimental Therapeutics, 298(3): 986-995.

Ibrahim G, Abdulmumin S, Musa KY,Yaro AH. 2008. Anticonvulsant activities of crude flavonoid fraction of the stem bark of Ficus sycomorus (Moraceae). Journal of Pharmacology and Toxicology, 3: 351356.

Ilodigwe EE, Akah PA, Nworu CS. 2010. Anticonvulsant activity of ethanol leaf extract of Spathodeacampanulata P. Beauv (Bignoniaceae). Journal of Medicinal Food, 13(4): 827-833.

Konate A, Sawadogo WR; Dubruc F, Caillard O,Guissou IP. 2012. Anticonvulsant effects of the Stem bark extract of Annonasenegalensis Pers. Molecular \& Clinical Pharmacology, 3(1): 62-72.

Moshi MJ, Kagashe GAB, Mbwambo ZH. 2005. Plants used to treat epilepsy by Tanzanian traditional healers. Journal of Ethnopharmacology, 97: 327-336.

N'Gouemo P, Koudogbo B, Pambou H, Tchivounda ANC, Minko EM. 1997. Effects of ethanol extract of Annonamuricata on pentylenetetrazolinduced convulsive seizures in mice. Phytotherapy Research, 11: 243-245.

Njamnshi AK, Angwafor SA, Jallon P, Muna WFT. 2009c. Secondary school students' knowledge, attitudes, and practice toward epilepsy in the Batibo Health DistrictCameroon. Epilepsia, 50(5): 1262-1265.

Njamnshi AK, Tabah EN, Yepnjio FN, Angwafor SA, Dema F,Fonsah JY, Kuate CT, Djientcheu VP, Angwafo III F, Muna WFT. 2009a. General public awareness, perceptions, and attitudes with respect to epilepsy in the Akwaya Health District, South-West Region, Cameroon. Epilepsy \& Behavior, 15: 179-185. 
Njamnshi AK, Yepnjio FN, Bissek ACZK, Tabah EN, Ongolo-ZP, Dema F, Angwafor SA, Fonsah JY, Lekoubou A,Angwafo III FF, Jallon P, Muna WFT. 2009b. A survey of public knowledge, attitudes, and practices with respect to epilepsy in Badissavillage, Centre region of Cameroon. Epilepsy \& Behavior, 16: 254-259.

Noumi E, Fozi FL. 2003. Ethnomedical botany of epilepsy treatment in FongoTongo village, Western province, Cameroon. Pharmaceutical Biology, 41(5): 330-339.

Pedersen ME, Vestergaard HT, Hansen SL, BahS, Diallo D, Jäger AK. 2009. Pharmacological screening of Malian medicinal plants used against epilepsy and convulsions. Journal of Ethnopharmacology, 121(3): 472-475.

Rastogi S, Pandey MM, Rawat AKS. 2011. An ethnomedicinal, phytochemical and pharmacological profile of
Desmodiumgangeticum (L.) DC. and Desmodiumadscendens (Sw.) DC. Journal of Ethnopharmacology, 136: 283-296.

Sandabe UK, Onyeyili AP, Chibuzo GA. 2003. Sedative and anticonvulsant effects of aqueous extract of Ficus sycomorus L. (Moraceae) stembark in rats. Veterinarskiarhiv, 73(2): 103-110.

Singh D, Goel RK. 2009. Anticonvulsant effect of Ficus religiosa: Role of serotonergic pathways. Journal of Ethnopharmacology, 123: 330-334.

Singh D, Mishra A, Goel RK. 2013. Effect of saponin fraction from Ficus religiosa on memory deficit and behavioral and biochemical impairments in pentylenetetrazol kindled mice. Epilepsy \& Behavior, 27(1): 06-11.

WHO. 2001. World health organization. Aidemémoire $\mathrm{N}^{\circ} 165$ : Epilepsie: Etiologie, épidémiologie et prognostic, WHO. 